\title{
Exceptionally Tall Individuals in a Relict Population of Actaea europaea (Schipcz.) J. Compton Against the Species of the Euro-Asiatic Cimicifuga Section
}

\author{
Marcin Kiedrzyński ${ }^{1 *}$, Józef Krzysztof Kurowski ${ }^{1}$, \\ Edyta Kiedrzyńska ${ }^{2,3}$, Piotr Maciejewski ${ }^{1}$ \\ ${ }^{1}$ Department of Geobotany and Plant Ecology, Faculty of Biology and Environmental Protection, University of Łódź, \\ Banacha 12/16, 90-237 Łódź, Poland \\ ${ }^{2}$ European Regional Centre for Ecohydrology of the Polish Academy of Sciences, \\ Tylna 3, 90-364 Łódź, Poland \\ ${ }^{3}$ Department of Applied Ecology, Faculty of Biology and Environmental Protection, University of Łódź, \\ Banacha 12/16, 90-237 Łódź, Poland
}

Received: 13 October 2015

Accepted: 3 December 2015

\begin{abstract}
The distribution of A. europaea indicates the relict character of its localities related to the Pleistocene and the Holocene evolution of vegetation. In 2011, a large population of $A$. europaea was discovered in central Poland. The measured plants are taller than those previously recorded in Poland and Europe, and also were the tallest of all the Asiatic and North American species. The aim of our paper is to present the height structure in populations of Actaea europaea in central Poland that contain probably the tallest known individuals of the Actaea genus. The study also discusses the factors that can influence the height of plants.
\end{abstract}

Keywords: Actaea, Sect. Cimicifuga, plant height, Ranunculaceae, relict population

\section{Introduction}

Actaea europaea (Schipcz.) J. Compton (Ranunculaceae) is the only species in Europe from section Cimicifuga [1]. Apart from the European taxon, the Cimicifuga section (L. ex Wernisch) DC also contains six Asiatic species, the nearest of which to Europe is Actaea cimicifuga $\mathrm{L}$. from Siberia $[1,2]$.

*e-mail:kiedmar@biol.uni.lodz.pl
However, A. europaea and A. cimicifuga are separated by $4,000 \mathrm{~km}$. This disjunction is probably a result of the Pleistocene extinction of the ancestor of A. europaea [1], implying that the current range of $A$. europaea could be recognized as a relict distribution on a broad EuroAsiatic scale. Furthermore, diffuse distribution of Actaea europaea also indicates its relict character on the European scale, and where it is related to the Holocene evolution of vegetation. Late glacial and early Holocene vegetation in Central Europe is interpreted in terms of analogues from extant southern Siberian vegetation, which typically 
comprises open forests with Actaea cimicifuga [3, 4]. Therefore, with the disappearance of early-Holocene open forest in Central Europe, resulting in the expansion of broad-leaved trees (e.g. Carpinus and Fagus), the current localities of $A$. europaea could be considered relict.

The main reasons for the current extinction of $A$. europaea is the decline of open forests as a result of human pressure, and the closing of the canopy by spontaneous succession [5]. The occurrence of Actaea europaea in Poland corresponds with the location of hotspots of thermophilous forest flora [6]. In 2011, a large population of C. europaea was discovered in central Poland [5] at the westernmost extent of its range in Europe. Detailed measurement of individuals shows that the stems grow to a considerable height.

The aim of the paper is to present the height structure of individuals in populations of Actaea europaea in central Poland that contain probably the tallest known individuals of the Actaea genus. The plant height structure of studied populations is compared with species from the Euro-Asiatic Cimicifuga section. Our study discusses the factors that can influence the height of plants.

\section{Materials and Methods}

\section{Characteristics of Studied Populations}

The population in Miejskie Pola (MP; $4.5 \mathrm{~km}$ southeast of the city of Przedbórz; Fig. 1) occurs at $245 \mathrm{~m}$ a.s.l. on a rather flat surface and comprises 350 plants, including more than 200 individuals with generative shoots. It inhabits thermophilous oak forest (Potentillo albae-Quercetum), with the density of a tree layer and understory of 50-60\%. In central Poland the oak forests also harbour other relict plants, e.g. Festuca amethystina [7]. The population in the Góra Krzemyk (GK; 8.8 km to the south of Miejskie Pola) grows at $315 \mathrm{~m}$ a.s.1., on the top and on the northern slope of a limestone hill and comprises 360 plants, about 100 of which are generative. Plants occur in thermophilous beech forest (Cruciata glabra-Fagus sylvatica community), with a tree density of $60 \%$ and shrub density ranging of $30-40 \%$.

\section{Analysis of Height Structure in Populations}

In 2013 and 2014 the height of the mature plants in the two above-described populations (Fig. 1) were measured. In the case of $A$. europaea, height of plant corresponds to the length of the longest orthotropic generative shoot. Statistical analyses associated with the height profile of the populations were performed using the Statistica 10 package [8]. The conservative Shapiro-Wilk test assessing the compliance of data distribution with normal distribution was used. Because of abnormal distribution of the results the nonparametric Kruskal-Wallistest (oneway ANOVA on ranks) with the post-hoc test to determine the significance of the differences between heights in populations and years, was used. The heights of the tallest individuals from the studied $A$. europaea populations

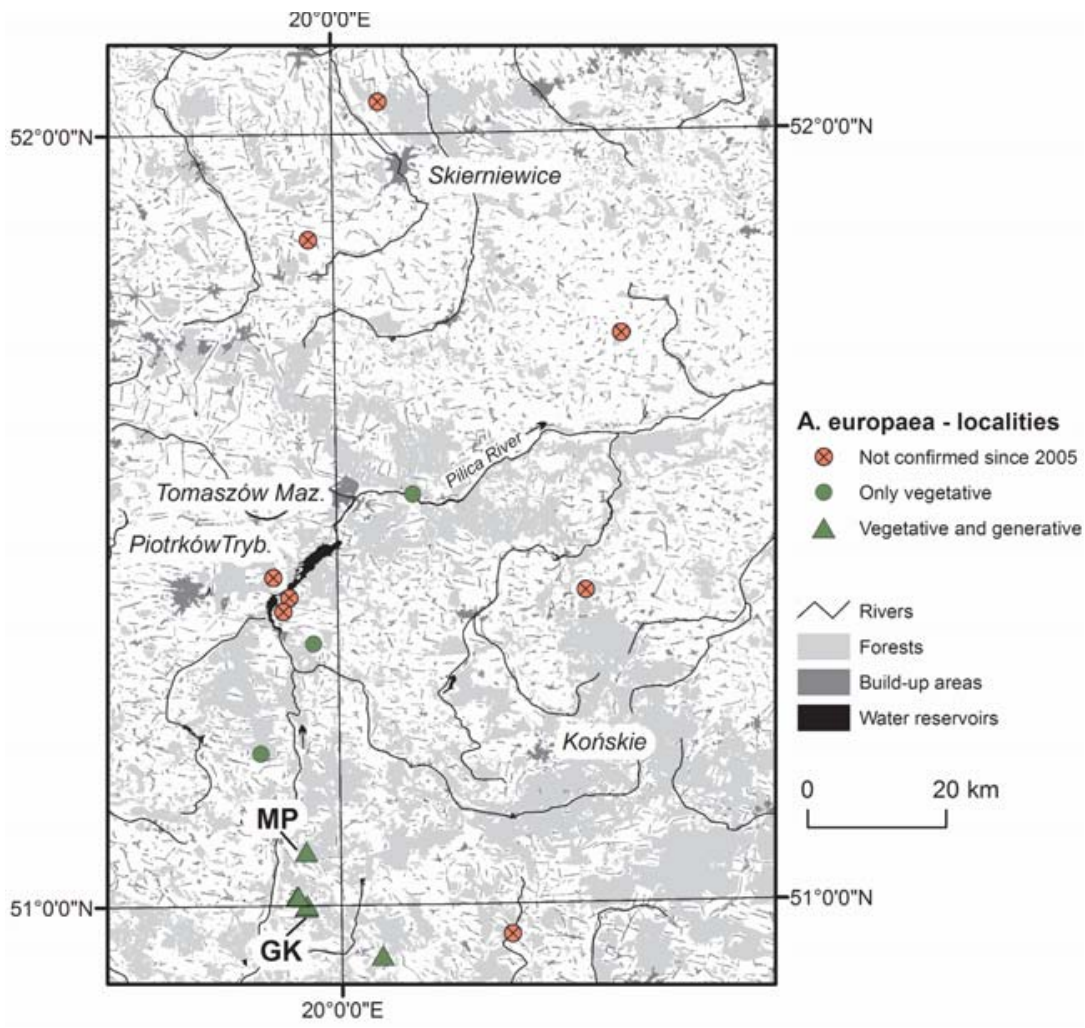

Fig. 1. The occurrence of Actaea europaea (Schipcz.) J. Compton in central Poland; studied populations: MP - Miejskie Pola, GK - Góra Krzemyk. 
Table. 1. Parameters of plant height in two populations of Actaea europaea in central Poland. Population: MP - Miejskie Pola, GK Góra Krzemyk; bold: the tallest known individuals of the Actaea genus.

\begin{tabular}{|c|c|c|c|c|c|c|c|c|}
\hline $\begin{array}{c}\text { Population/ } \\
\text { year }\end{array}$ & $n$ & Mean & Median & Min. & Max. & SD & SE & Individuals with at least $220 \mathrm{~cm}$ high \\
\hline $\mathrm{MP} / 2013^{\mathrm{a}}$ & 43 & 178.8 & 171.0 & 121 & 289 & 37.5 & 5.7 & $237,238,248, \mathbf{2 5 1 , 2 6 6 , 2 8 9}$ \\
\hline $\mathrm{MP} / 2014^{\mathrm{b}}$ & 53 & 193.1 & 191.0 & 125 & 269 & 33.5 & 4.6 & $\begin{array}{c}220,221,222,225,233,236,238,238, \\
\mathbf{2 6 0 , 2 6 4 , 2 6 9}\end{array}$ \\
\hline $\mathrm{GK} / 2013^{\mathrm{c}}$ & 24 & 140.8 & 123.5 & 97 & 222 & 36.4 & 7.4 & 222 \\
\hline $\mathrm{GK} / 2014^{\mathrm{d}}$ & 62 & 155.6 & 155.0 & 93 & 219 & 28.8 & 3.6 & - \\
\hline
\end{tabular}

P-values of post-hoc tests in Kruskal-Wallis nonparametric ANOVA: a-b $(p=0.2104)$, a-c $(p=0.0011)$, a-d $(p=0.0207)$, b-c i b-d $(p$ $=0.0000), \mathrm{c}-\mathrm{d}(p=0.7542)$

were compared with other species from the Euro-Asiatic Cimicifuga section [2, 9-11].

\section{Results and Discussion}

The tallest individuals of A. europaea were measured in the Miejskie Pola population. Of measured plants, in
2013 six (14\%) were taller than $220 \mathrm{~cm}$, and in 2014 $11(20 \%)$ (Table 1). All of those specimens are taller than previously recorded in Poland [9] and Europe [2] (Fig. 2). Moreover, the tallest individuals from Miejskie Pola were also taller than any known specimen belonging to all species from the Euro-Asiatic Cimicifuga section [2, 10-11] (Figs 2, 3), whose tallest individuals $(250 \mathrm{~cm})$ were only previously described in Actaea frigida from China

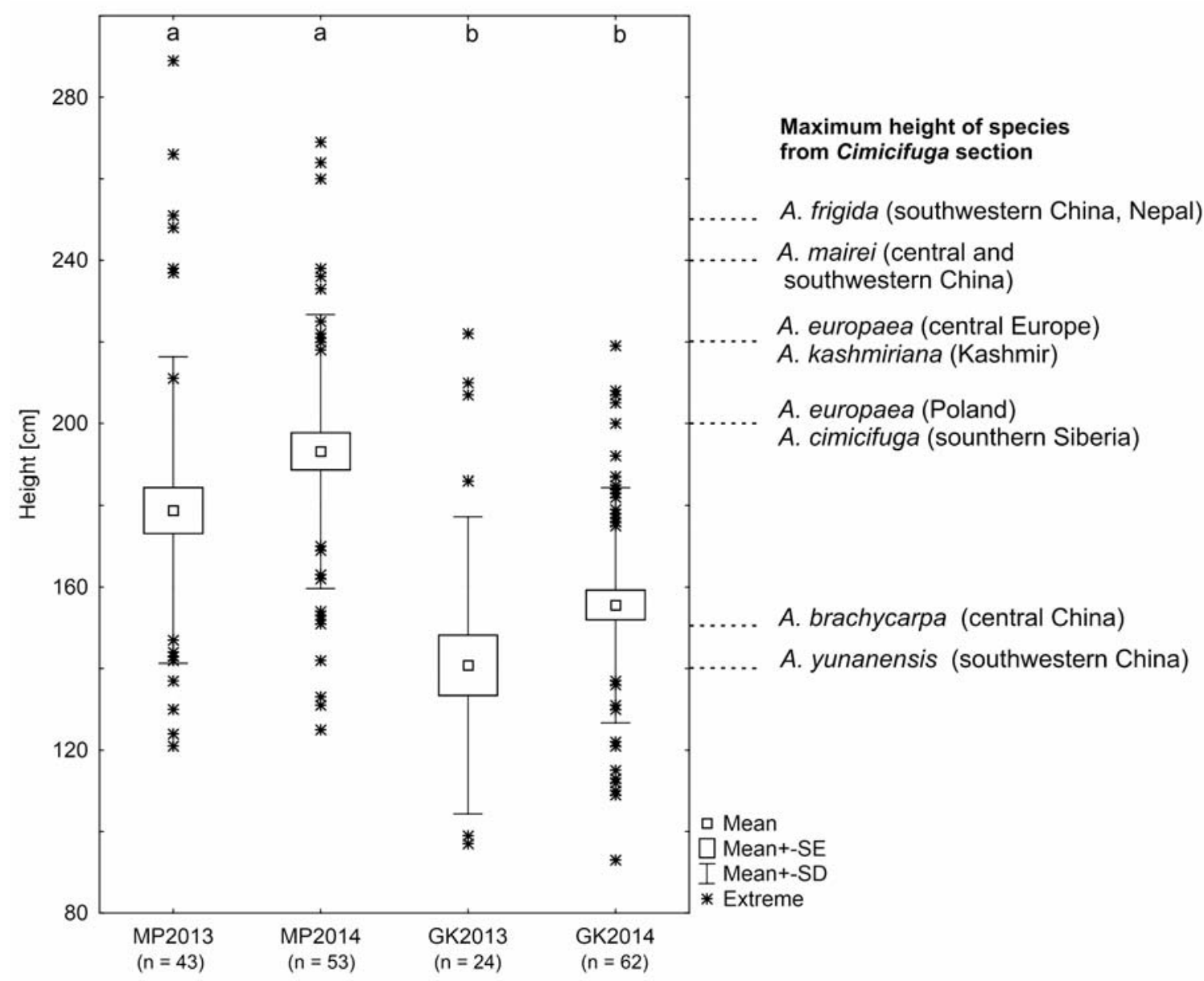

Fig. 2. Height structures of A europaea (Schipcz.) J. Compton in Miejskie Pola (MP) and in Góra Krzemyk (GK) in central Poland. On the right: maximum height in species of Euro-Asiatic Cimicifuga section (L. ex Wernisch) DC, according to Kucowa [9], Compton and Hedderson [2], Li and Brach [10], and Ren et al. [11]. The letters on the top indicate significant differences in means according to posthoc testing $(\mathrm{p}<0.05)$ done after the Kruskal Wallis nonparametric ANOVA. 
and Nepal [11]. Outside the Cimicifuga section, tall plants of up to 248-250 $\mathrm{cm}$ were also identified in the North American Actaea racemosa (Actaea section) [12]. Hence, the discovered population in Miejskie Pola is probably the population with the tallest known individuals of the whole Actaea genus.

The mean height of plants in Góra Krzemyk was in 2013 and 2014 significantly lower than those taken from the Miejskie Pola population (Table 1, Fig. 2). However, the standard deviations (SD) were similar in both populations (Table 1).

Of 26 studied A. racemosa populations in the United States (which are not part of the Cimicifuga section), only one had higher height mean value $(198.6 \mathrm{~cm})$ [12] than the population of A. europaea in Miejskie Pola (191.0 cm in 2014). However, the maximum height of mature individuals of the North American A. racemosa populations $(248 \mathrm{~cm})$ was lower than that of the Miejskie Pola population $(289 \mathrm{~cm})$.

Previous studies report that heights of the A. europaea individuals range from 50 to $180(220) \mathrm{cm}$ [2]. Hence, the height range of generative plants in the Miejskie Pola population was similar to those of the species as a whole.

In both studied populations, the means of plant height were higher in comparison year to year, but these differences were not statistically significant (Fig. 2, Table 1). However, in the Miejskie Pola population, exceptionally tall individuals grew in both studied seasons. The above result show that the height of the Actaea europaea individuals may depend on environmental (climatic, habitat) conditions.

The differences between heights of individuals in studied populations could be the result of local habitat conditions. One of the main factors influencing plant height is light availability. Hence, the exceptionally high growth of Actaea europaea in the Miejskie Pola could be in accordance with general phytocoenoses structures, meaning a more open structure of stands in the oak forests than in the beech forests. However, the population in Góra Krzemyk, which occurs under the beech trees, is located on the hill slope and near the edge of the forest, where the light is also well available (at least for some individuals in population). Moreover, the additional plant height measurements done in the region showed that the maximum growth of A. europaea in the oak forest in the Korzecko locality (more than $40 \mathrm{~km}$ away from studied populations) did not exceed $220 \mathrm{~cm}$ (Kiedrzyński 2014, unpublished data). Furthermore, observations of A. europaea in the Botanical Garden of the Faculty of Biology and Environmental Protection at the University of Lodz, where they were planted in 1985 and have grown in full light conditions, indicated that the tallest shoots did not exceed $235 \mathrm{~cm}$ (Kiedrzyński 2013-15, unpublished data). Hence, the analysis of only the light factor does not explain the enormous height of the A. europaea population in Miejskie Pola. Taking into consideration the statements above, we have concluded that detailed studies of habitat conditions in the relict localities of Actaea europaea in central Poland should be conducted in the future.

Some general relationships can be observed between elevation and the maximum height of Actaea (section Cimicifuga) plants. Compton and Hedderson [2] divided Actaea cimicifuga from Siberia (Fig. 3) into two varieties: var. foetida, which grows to up to $2 \mathrm{~m}$ height and occurs between 150-3,500 $\mathrm{m}$ a.s.l., and var. racemosa, which grows up to $0.8 \mathrm{~m}$ but occurs only in mountains from 2,100 to 3,500 $\mathrm{m}$ a.s.l. The second example concerns central Asian species. Actaea yunanensis from southwestern China grows to only $1.4 \mathrm{~m}$ tall [10] (Fig. 2) and is found at the highest altitudes (2,800-4,500 m) compared to the other species from the Cimicifuga section [2, 10]. Conversely,

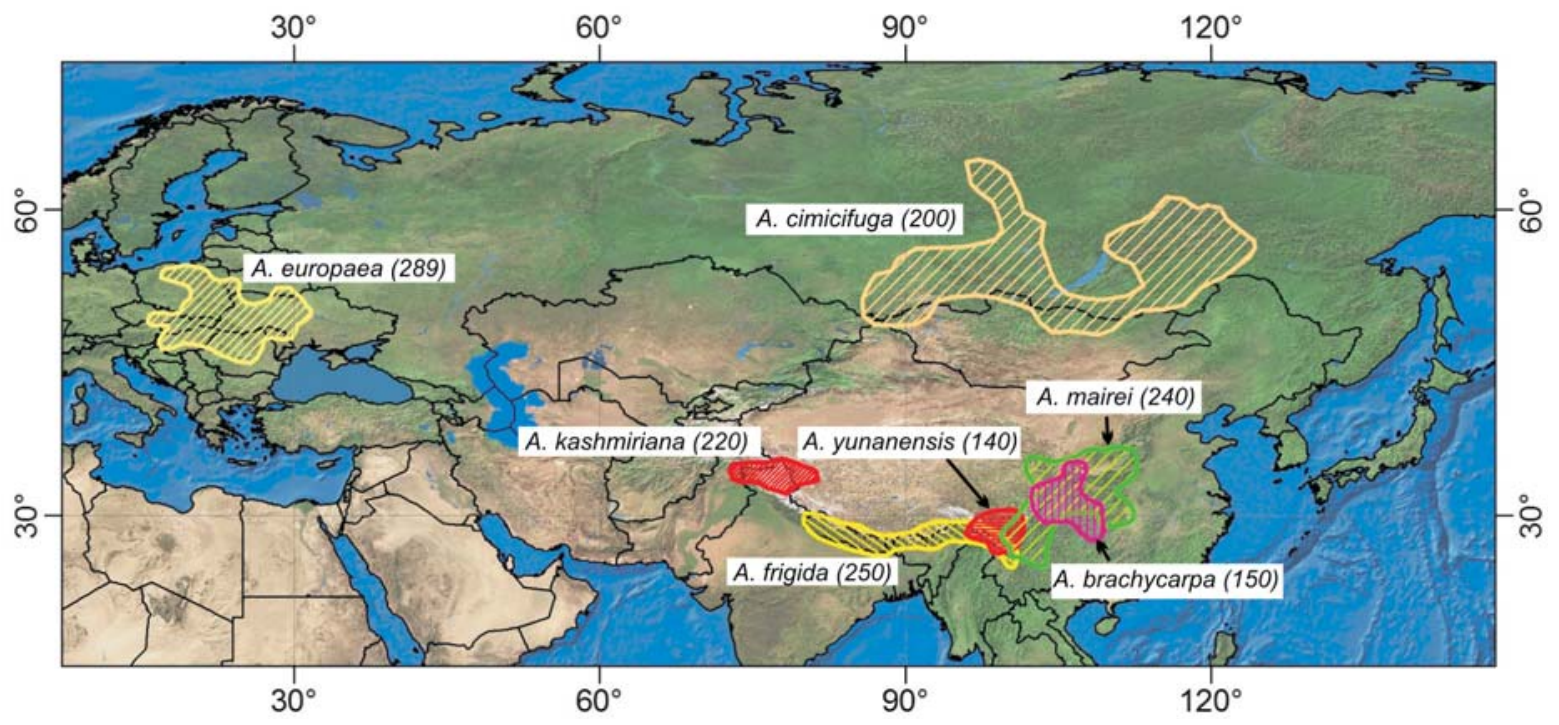

Fig. 3. Distribution of Cimicifuga section (L. ex Wernisch) DC with maximal height (in $\mathrm{cm}$ ) for species. Species ranges and height values according to our own results and Compton and Hedderson [2], Compton et al. [1], Li and Brach [10], and Ren et al. [11]. Note that the species ranges have not yet been sufficiently researched in literature in detail, and this should be a topic for future studies. 
A. mairei and A. kashmiriana, two central Asiatic species which grow above $2.2 \mathrm{~m}$ tall, occur as low as 1,900 and $2,500 \mathrm{~m}$ a.s.1., respectively. It is reasonable to assume that the growth of Cimicifuga section plants could be higher at lower elevations.

The lowland location of studied populations in central Poland with enormously tall specimens confirms the above assumption. The population in Miejskie Pola occurs at rather lower altitudes ( $245 \mathrm{~m}$ a.s.1.) than those recorded for A. europaea in Europe (100-1,400 m) [2] and compared to the highest locations of species in Poland $(1,220-$ 1,240 $\mathrm{m}$ in the Tatra Mountains) [13].

Plant height in the Cimicifuga section could also depend on the ploidy level. Yang [14] suggests that tetraploid plants $(2 n=32)$ are taller, have larger leaflets and fruits, and it are quite straightforward to distinguish tetraploid and diploid $(2 \mathrm{n}=16)$ plants in the field. The recognition of cytotypes supports the taxonomic status of A. frigida as described by Ren et al. [11], which until now have been thought to be the tallest plants in the Cimicifuga section (Figs. 2, 3). Ren et al. [11] assumed that tetraploidy is a phenomenon currently described only in the case of $A$. frigida, and suggests that the unknown ploidy level of $A$. kashmiriana (also a tall and robust species) is worthy of attention in the future. Actaea europaea has been described as diploid $(2 n=16)$ [15]. Based on the above findings, an important task of future research would be to investigate the ploidy levels of the studied populations in central Poland.

\section{Conclusions}

Results and considerations presented in our paper indicate that the studied populations of Actaea europaea in central Poland have great potential in the research area of biogeography, ecology, and evolution of relict populations. We have also concluded that detailed studies of habitat conditions in localities of Actaea europaea should be conducted for the assessment of their current refugial capacity.

\section{References}

1. COMPTON J.A., CULHAM A., JURY S.L. Reclassification of Actaea to include Cimicifuga and Souliea (Ranunculace$a e)$ : phylogeny inferred from morphology, nrDNA ITS, and cpDNA trnL-F sequence variation. Taxon. 47, 593, 1998.
2. COMPTON J.A., HEDDERSON T.A.G. A morphometric analysis of the Cimicifuga foetida L. complex (Ranunculaceae). Bot J Linn Soc. 123, 1, 1997.

3. KUNEŠ P., PELÁNKOVÁ B., CHYTRÝ M., JANKOVSKÁ V., POKORNÝ P., PETR L. Interpretation of the lastglacial vegetation of eastern-central Europe using modern analogues from southern Siberia. J Biogeogr. 35, 2223, 2008.

4. CHYTRÝ M., DANIHELKA J., KUBEŠOVÁ S., LUSTYK P., ERMAKOV N., HÁJEK M., HÁJKOVÁ P., KOČÍ M., OTÝPKOVÁ Z., ROLEČEK J., ŔEZNÍČKOVÁ M., ŠMARDA P., VALACHOVIČ M., POPOV D., PIŠÚT I. Diversity of forest vegetation across a strong gradient of climatic continentality: Western Sayan Mountains, southern Siberia. Plant Ecol. 196, 61, 2008.

5. KIEDRZYŃSKI M., ANDRZEJEWSKI H. Cimicifuga europaea Schipcz. European cohosh. In: Olaczek R. editor. The Red Book of Plants of Lodz Province. Endangered vascular plants. Endangered plant communities. . Botanical Garden in Łódź. University of Łódź, 64. 2012.

6. KIEDRZYŃSKI M., JAKUBOWSKA-GABARA J. The detection of thermophilous forest hotspots in Poland using geostatistical interpolation of plant richness. Acta Soc Bot Pol. 83 (3), 183, 2014.

7. KIEDRZYŃSKI M., ZIELIŃSKA K.M., KIEDRZYŃSKA E., JAKUBOWSKA-GABARA J. Regional climate and geology affecting habitat availability for a relict plant in a flat landscape: the case of Festuca amethystina L. in Poland. Plant Ecol Divers. 8 (3), 331, 2015.

8. STATSOFT INC [Internet]. STATISTICA (data analysis software system), Available from: http://www.statsoft.com, version 10, 2011.

9. KUCOWA I. Cimicifuga L., Cohosh. In: Jasiewicz A. editor. Flora of Poland. Vascular plants. PWN. Warsaw-Cracow. IV, 24, 1985.

10. LI L., BRACH A.R. Cimicifuga Wernisch. In: Wu Z.Y., Raven P.H., Hong D. editors. Flora of China, Vol. 6. Science Press, Miss. Bot. Gard. Press. 144, 2001.

11. REN CH., YUAN Q., YANG Q.E. Cytological evidence supports the taxonomic status of the Sino-Himalayan species Cimicifuga frigida (Ranunculaceae). Nordic J Bot. 30 (5), 513, 2012.

12. GARDNER Z.E., LUECK L., ERHARDT E.B., CRAKER L.E. A morphometric analysis of Actaea racemosa L. (Ranunculaceae). J Med Act Plants. 1 (2), 47, 2012.

13. MIREK Z., OKLEJEWICZ K., VONČINA G., WRÓBEL I. European cohosh (Foetid Cohosh) Cimicifuga europea Schpicz. In: Mirek Z., Piękoś-Mirkowa H. editors. The Red Book of Polish Carpathians. Vascular plants. Cracow. Institute of Botany PAS. . 86, 2008.

14. YANG Q.E. Karyomorphology of four species in Cimicifuga (Ranunculaceae) from China, with some cytogeographical notes on C. foetida. Acta Phytotax Sin. 37 (5), 433. 1999.

15. MOORE D. M. Flora Europaea Check-List and Chromosome Index. Cambridge University Press. 2009. 
